\title{
Customer Loyalty Indicator of Mobile Payment Application in the Financial Service Industry: A Study of LinkAja
}

\author{
Dewi Tamara, Fifi Roesmawi, Haras Febria, Izma Dwi Ariesta \\ * Magister Manajemen BINUS Business School, Universitas Bina Nusantara, Jl. Hang Lekir I No. 6, \\ Senayan, Kebayoran Baru, Jakarta Selatan, DKI Jakarta, Indonesia
}

\begin{abstract}
:
Purpose - The main purpose of this journal is to analyse on performance expectation, effort expectation, social influence, facilitating condition, hedonic motivation, perceived technology security, and trust toward the customer loyalty of using LinkAja.

Research limitations/implications - This research presents the sample population of 197 participants responded to the survey in Indonesia in Java area, whereby 175 out of the number defined as users of LinkAja are valid responses that have been obtained for statistical analysis.

Methodology/approach - Data collection used in this journal are questionnaire and purposive sampling methods. This research has examined provided data and information through quantitative research with Multiple Linear Regression analysis method.

Findings - This research found that four independent variables, i.e. effort expectation, social influence, hedonic motivation, and trust are influencing the dependent variable of customer loyalty in using LinkAja. The result shows a performance expectation, facilitating condition and perceived technology security do not significantly influence customer loyalty.

Practical implications - There are 4 (four) main significant factors to maintain the customer loyalty of mobile payment application i.e. effort expectation, social influence, hedonic motivation, and trust
\end{abstract}

Keywords: customer loyalty, mobile payment application, linkaja, Indonesia, social influence

\section{Introduction}

The technology for online mobile application has been developed swiftly nowadays. Technology development is currently promoting intense business world competition, which requires company to creatively meeting business needs and continue to innovate. Smartphones are now one of the most essential consumer goods ever introduced in this new digital age (Aydin \& Burnaz, 2016). The number of mobile phone users has been relentless grown in recent years, motivated by the advancement of modern life mobility, and followed by the mobile phone market has grown pointedly (Schierz et al., 2010). Not to mention that almost companies always try to launch various popular mobile application to have possession of both new and existing customers (Boyd, Kannan, \& Slotegraaf, 2019). Mobile payment service is a new tool in the payment system in which money can be transferred electronically through mobile application (Popovska-Kamnar, 2014). Electronic transactions via handheld devices offer consumers the ability to make payments efficient, comfortable and useful (Phonthanukitithaworn et al., 2016). Companies can attract consumers with the electronic payment through mobile application.

In 2019, the amount of internet users in Indonesia is more than 150 million, calculated based on 56\% from Indonesia's population of 268.20 million (Basari, 2019). Indonesia is moving from cash to cash-less transaction society, as Multazam (2019) stated that electronic money transactions using digital wallet in Indonesia was increased three folds from 2017 at Rp12.4 trillion to Rp47.2 trillion in 2018. 
LinkAja is one of the top 5 (five) mobile payment applications (iprice.co.id, 2019). It was originated from TCash from Telkomsel. Telkomsel has 15 million users in Indonesia (Katadata.co.id, 2018). Although Telkomsel has the biggest number of customers in Indonesia for mobile phone provider, Telkomsel's users are not attracted to use T-cash mobile payment application. To expand the use of T-Cash, Telkomsel integrates TCash with mobile payment services provided by state-owned banks, Bank Mandiri's e-cash, BNI's UnikQu, Telcom's T-Money, and BRI's T-Bank (Thejakartapost.com, 2019) and rename it as LinkAja. However, despite Telkomsel is the biggest mobile phone operator in Indonesia as well as the effort to integrate and promote Link-Aja, LinkAja has moved down to fourth place from the top three of the most popular mobile payment applications as shown in Figure 1.

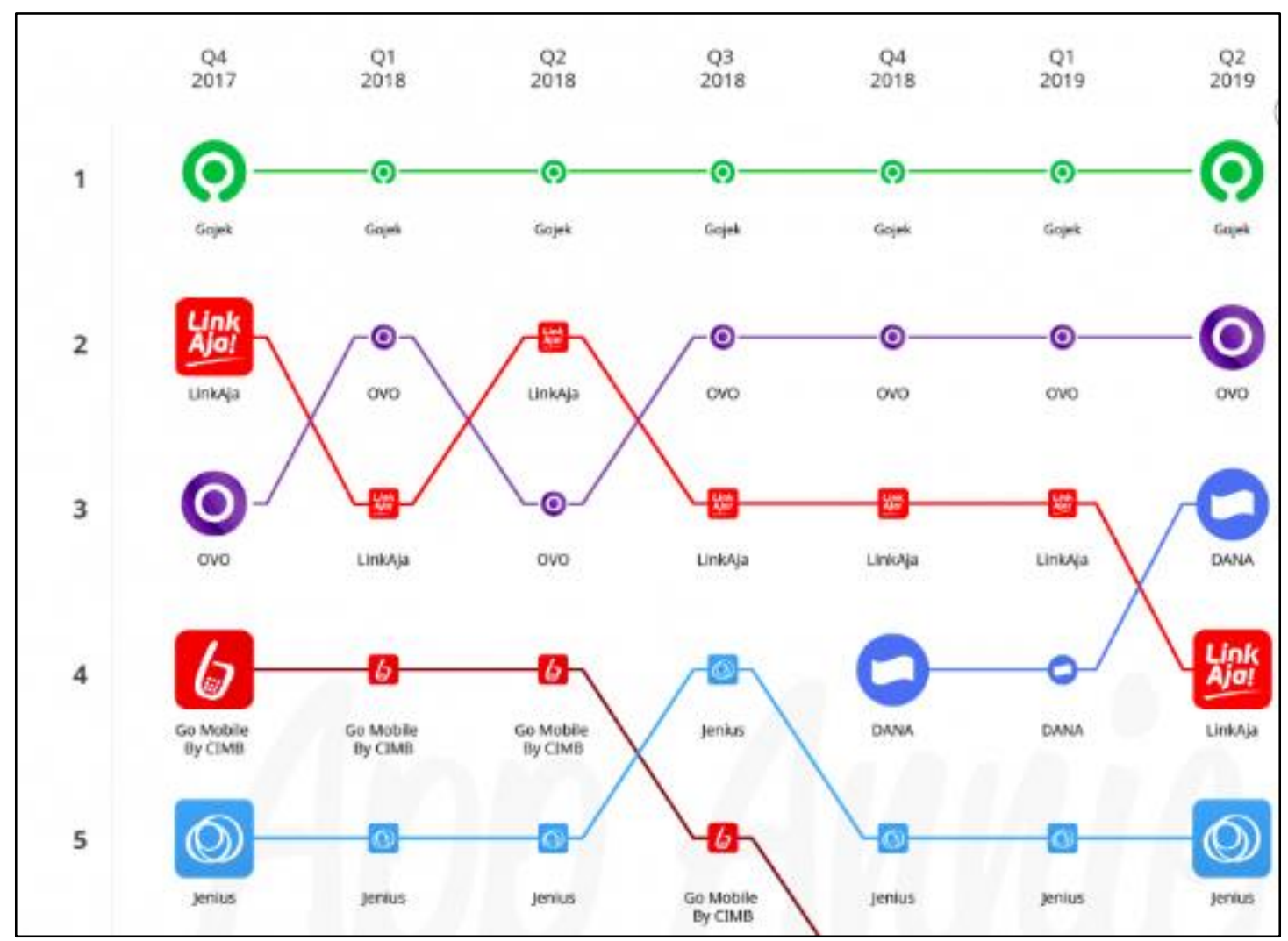

Figure 1: The most popular of Mobile Payment in Indonesia (Iprice, 2019)

The research objective is to understand why Link Aja's performance is decreasing while other mobile payment application can maintain or increase their position. Researchers elaborate the study pertaining the customer loyalty based on 2 (two) previous studies by Alalwan et al. (2017) and Oliveira et al. (2016) by using UTAUT-2 (Unified Theory of Acceptance and Use of Technology-2) methodology. Based on the 2 (two) studies, researchers use theory model combined through trust and perceived technology security variables on behavioural intention of LinkAja in Jakarta and the surrounding city, i.e. Bogor, Depok, Tangerang and Bekasi (Jabodetabek).

This paper adopted with literature review describes the concept of mobile payment, previous research and UTAUT-2 models, then followed by research method, analysis, results and conclusions.

\section{Literature Review}

\subsection{Mobile Payment}

A mobile payment service is considered a distinctive electronic handling of payment service which is using mobile communication devices to transfer of monetary value (Schierz et al., 2010). Fan, et al. (2018) described that a mobile payment or e-payment is a payment method whereby the commercial transaction is initiated, authorized and confirmed by a mobile device. In addition, according to Kim et al., (2010), epayment is defined as transferring a value of payment transaction through electronic mechanism from a 
payer to a payee. It can be in a form of internet banking application, or from the $3^{\text {rd }}$ (third) party non-bank mobile application. According to Oliveira, et al. (2016), a mobile payment is defined as a process amongst 3 (three) parties i.e. customer, merchant, and the bank, in contrast with internet banking whereby it is a simple direct consumer-bank relation.

\subsection{Previous Research}

As described by Oliveira, et al. (2016), a mobile payment is different with mobile banking; the study of mobile payment is not as widely conducted as for mobile banking. Only several prior studies explored the customer loyalty to use mobile payment.

The extended UTAUT-2 was proposed by Venkatesh et al. (2012) consists of hedonic motivation, price value, and habit to the original version of UTAUT (Venkatesh et al. 2003) which consists of performance expectation, effort expectation, social influence, and facilitation conditions (Gupta et al., 2018).

Based on previous analyses conducted by Oliveira et al. (2016), there are 7 (seven) variables drive the behavioural intention, i.e. performance expectation, effort expectation, social influence, facilitating condition, hedonic motivation, price value, and habit. In this study, the researchers are seeking to understand customer loyalty which are determined by behavioural intention in using the mobile payment system. The result of the study shows performance expectation, social influence, loyalty to adopt, and perceived technology security indicators have a tangible and intangible significant impact on loyalty to use mobile payment.

To indicate the frequent usage of mobile payment, the previous research taken by Alalwan et al. (2017) has eight constructs i.e.: performance expectation, effort expectation, social influence, hedonic motivation, price value, trust, and behavioural intention. The result of the study confirmed performance expectancy, effort expectancy, hedonic motivation, price value, and trust were significant predictors of the loyalty. Both of loyalty and facilitating condition were also supported to be significant factors predicting the actual adoption of mobile payment.

\subsection{Adoption Models}

While there were many adoption theories based on the literature review (Morosan \& DeFranco, 2016), UTAUT-2 has been chosen as the main theoretical foundation because it provides a clear depiction on the fundamental relationship of the system perceptions amongst performance, effort, and behaviour (e.g. intentions, loyalty). The relationship of each of the construct in UTAUT-2 is described in Figure 2.

\subsubsection{Behavioural Intention}

Behavioural intention defines as consumers behaviour showing a loyalty or supportive to the company in order to recommend it to other people because they have received good service from the company (Namkung \& Jang, 2007), thus behavioural intention is a good customer loyalty indicator. Haixia Lv et al. (2018) stated that customer loyalty is impacted by customer satisfaction and behavioural intention. Behavioural intention is considered to be defined by the subjective possibility of the particular behaviour of an individual and reflects the individual willingness to adopt a person's behaviour, said by Shiau (2014). Saha and Theingi (2009) also defines behavioural intention is an intention and loyalty of buying back or a service provider as supported by the customer's ability to do something positive about a service provider to other people. Based on the above-mentioned, researchers will peruse the LinkAja's customer loyalty based on the behavioural intention indicator by adopting the variables from UTAUT-2 which also supported by the study by Alalwan et al., (2017) and Oliveira et al. (2016).

The following below are the 7 (seven) constructs in which the researchers have developed the hypothesis on this study:

\subsubsection{Performance Expectation}

Performance expectation is defined by the degree for which using a technology in certain activities will 
benefit consumers (Venkatesh, 2012. Performance expectancy also has considered as a main indicator as it can provide strong predictions of technology use of interest. The perception of an individual uses a mobile payment to achieve advantages in payment tasks will affect the behavioural intention of mobile payment adoption (Oliveira et al., 2016). Alalwan et al. (2017) described that the encouragement of individual needs to employ a new technology is when the individual has obtained the advantage of using such technology in daily activities.

\subsubsection{Effort Expectation}

Effort expectation defines as a degree of easiness which related with the use of a system (Venkatesh et al., 2003). Once users feel a system is simple to use and take a minimum effort, they will expect higher performance of the system. The effort expectation plays a key role in determining customers intention to use a technology (Alalwan et al., 2017).

\subsubsection{Social Influence}

Social influence is characterized to what extent consumers perceive that important to others such as family and friends to use a particular technology (Venkatesh et al., 2012). Alalwan et al. (2017) described the social influence is a key defining factor of behavioural intention.

\subsubsection{Facilitating Condition}

Facilitating condition defines as a degree to which a person considers an organizational and technical technology is available to support the use of the system (Venkatesh et al., 2003). Venkatesh et al. (2012) further refines the facilitating condition shall refer to as resources and support available of consumer perceptions to conduct any behaviour. The behavioural intention which is in this analysis is linked to customer loyalty is positively correlated the operational infrastructure and supports mobile payment (Oliveira et al., 2016)

\subsubsection{Hedonic Motivation}

Hedonic motivation refers as an excitement or pleasure feeling derived from using a technology, and it has been shown to play an important role in determining technology acceptance and usage (Venkatesh et al., 2012). Hedonic motivation becomes an important determinant of the adoption and utilization of technology for the customer. Hedonic motivation is fundamental to human experience and behaviour. Mobile payments as a new form of financial transactions are enjoyable for users of which leading to their acceptance (Oliveira et al., 2016).

\subsubsection{Perceived Technology Security}

Security is one of the challenges of generally building e-payments. Researchers added Perceived technology security is a variable instead of a price value as in UTAUT-2. Perceived technology security defines a degree to which people believes certain technology or service are safe (Kim et al., 2010). The extent of security is perceived safe in mobile payment if people believe that while using mobile payment their assets and privacy information is secure. The higher the perceived safety of consumers the less risks that they perceive and therefore more willing to adopt a technology (Fan et al., 2018). Consumer mobile payment expectancy will be impacted by consumer confidence in LinkAja interest. Security can be a major challenge in this study when building LinkAja system to encourage and maintain the intention of customers to keep using LinkAja.

\subsubsection{Trust}

In addition to perceived technology security, researchers also change the variable Habit from the UTAUT-2 to Trust. Trust has received considerable attention due to the uncertainty and risk involved in a lot of online transactions in e-commerce business. Trustworthiness has been found to impact the adoption of different services by users, such as Internet banking (Lu \& Yu., 2009). Carlos Roca et al., (2008) elaborate the trust definition from a social psychologist perspective that trust is characterized in expectation and willingness of the trusting party engaging in a transaction. Trust should be one of the factors that affect online transactions because individuals do not have direct control with merchants. The results from Zhou (2013) study indicated that service quality is the main factor affecting trust. Trust can be used determine the behavioural intention 
of mobile payment's customers.

\section{Research Model and Hypothesis}

\subsection{Research Model}

This research model in Figure 2 below showed the relationship between variables and the hypothesis which was adopted from Venkatesh et al. (2012), Oliveira et al., (2016) and Alalwan et al., (2017).

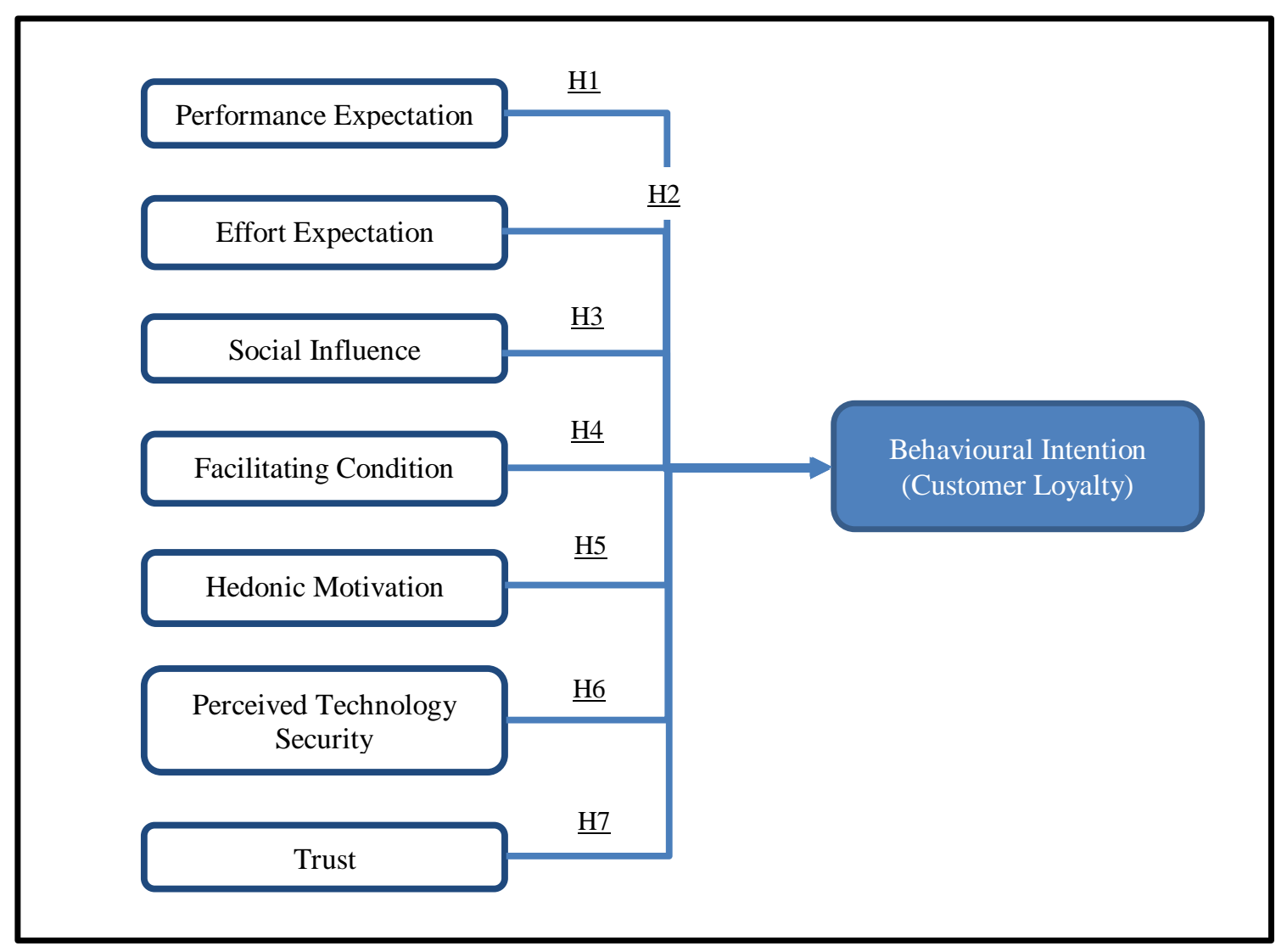

Figure 2: Research Model

3.2. Hypothesis

3.2.1. Performance Expectancy

Based on the literature review, the performance expectancy positively affects the behavioural intention. However, most of LinkAja's customers are young generation which may not require high performance application to help them in daily activities.

H1: Does performance expectancy has a significant impact on the loyalty of LinkAja's customers?

\subsubsection{Effort Expectancy}

Customer of LinkAja expects easy to operate the application, which means take minimal effort to perform daily needs such as money transfer and bills payment.

H2: Does effort expectancy has a significant impact on the loyalty of LinkAja's customers?

\subsubsection{Social Influence}

The influence of surrounding people and word of mouth will increase the popularity of LinkAja and in turn will impact the loyalty of LinkAja's customer.

H3: Does social influence has a significant impact on the loyalty of LinkAja's customers?

\subsubsection{Facilitating Conditions}

Customers of LinkAja requires call centre or customer service support which should be available 24 hours 7 days. This service can use the recent technology such as whatsapp, chatbot, line, etc. The 
response time of the call centre or customer service is part of facilitating condition

H4: Does facilitating condition have a significant impact on the loyalty of LinkAja's customers?

\subsubsection{Hedonic Motivation}

Based on the literature review above, the fun and enjoyable application interface will attract the loyalty of Link Aja's customers.

H5: Does hedonic motivation has a significant impact on the loyalty of LinkAja 's customers?

\subsubsection{Perceived Technology Security}

Consumer mobile payment expectancy will be impacted by consumer confidence in LinkAja interest. Security can be a major challenge in this study when building LinkAja system to encourage and maintain the intention of customers to keep using LinkAja.

H6: Does perceived technology security has a significant impact on the loyalty of LinkAja's customers?

\subsubsection{Trust}

There are many factors to increase trust for Link Aja customers. The service quality, reliability of the system, certainty of secure transactions and customer data are among of the factors.

H7: Does trust have a significant impact on the loyalty of LinkAja's customers?

\section{Research Method}

\subsection{Measurement}

The researchers developed the questionnaire based on construct and items from literature review. Quantitative method is used to examine a particular population or sample (Sugiyono, 2010). The researchers went through questionnaires to collect data and inspect the quantitative method relationships amongst variables. The main questions (excluding the filtering question and demographic questions) consist of 35 questions. All items were measured using Likert scales within 1 ("strongly disagree") to 5 ("strongly agree") ranging to measure respondents' attitude in a validated way. Measurement on (i) the performance expectation, effort expectation, social influence, facilitating condition, and hedonic motivation are adapted from Venkatesh et al. (2012), (ii) perceiving technology security are adapted Oliveira et al. (2016), and (iii) trust are adapted from Kim et al. (2009).

\subsection{Sample and Data collection}

The target population in this research is narrowed to LinkAja's customer and lived in Jabodetabek. There are 197 participants responded to the survey, out of which 175 are valid responses were obtained for statistical analysis defined as users of LinkAja and lived in Jabodetabek. Since the population characteristic cannot be specified, researchers use the non - probability sampling techniques in which the process does not give such population equal chance to be selected to be a sample. In Sugiyono (2010), the size of samples can be calculating by using the formula below:

$$
\mathrm{N}=5 \times \mathrm{Q}=5 \times 35=175 \text { Samples }
$$

\section{$\mathrm{N}$ : Total Sample \\ Q: Question}

The summary of respondent's demographic is presented in Table 1.

\begin{tabular}{|l|l|r|r|l|}
\hline Characteristic & n & \% & \\
\hline Gender & Female & 56 & $32.0 \%$ & \\
\hline & Male & 119 & $68.0 \%$ & \\
\hline & & & & \\
\hline Age & $<20$ years & 32 & $18.3 \%$ & \\
\hline
\end{tabular}




\begin{tabular}{|l|l|r|r|r|}
\hline & $21-30$ years & 134 & $76.6 \%$ & \\
\hline & $31-40$ years & 9 & $5.1 \%$ & \\
\hline & 40 and above years & 0 & $0.0 \%$ & \\
\hline & & & & \\
\hline Education & High school & 83 & $47.4 \%$ & \\
\hline & Bachelor & 88 & $50.3 \%$ & \\
\hline & Graduate & 4 & $2.3 \%$ & \\
\hline & Post Graduate & 0 & $0.0 \%$ & \\
\hline & & 97 & $55.4 \%$ & \\
\hline Occupation & Student & 52 & $29.7 \%$ & \\
\hline & Employee & 9 & $5.1 \%$ & \\
\hline & Civil Servant & 3 & $1.7 \%$ & \\
\hline & State Owned Company & 14 & $8.0 \%$ & \\
\hline & Other & & & \\
\hline
\end{tabular}

Table 1. Demographic characteristic of respondents

\section{Data Analysis}

5.1. Reliability and validity test

In this research, for reliability test the researchers use the Cronbach's alpha. Based on Kim et al. (2010) this Cronbach's alpha it the most popular method for measuring reliability. Researchers using SPSS to process the data to get Cronbach's alpha score. The Cronbach's alpha score in this research is above 0.7. Table 2 shows the Cronbach's Alpha score of each variable. At early stage of research, a reliability scores above 0.60 is sufficient (Kim et al., 2010). We see all of the variables are above 0.7. There are 4 variables above 0.9 i.e. performance expectation, effort expectation, hedonic motivation, and perceived technology security, while the rest of variables are above 0.7. The Table 2 reveals that all constructs have high internal consistency reliability.

\begin{tabular}{|l|c|c|}
\hline \multicolumn{1}{|c|}{ Variable } & Item & Cronbach's Alpha \\
\hline Performance_Expectation & 6 & 0.896 \\
\hline Effort_Expectation & 4 & 0.869 \\
\hline Social_Influence & 3 & 0.799 \\
\hline Facilitating_Condition & 4 & 0.703 \\
\hline Hedonic_Motivation & 4 & 0.866 \\
\hline Perceived_Technology_Security & 3 & 0.860 \\
\hline Trust & 7 & 0.936 \\
\hline Behavioural_Intention & 4 & 0.942 \\
\hline
\end{tabular}

Table 2. Reliability test result

For validity testing in this research is using 2 (two) tailed through a criteria of significant rate $(\alpha) 0.05$. All data in this research is valid based on the result in Table 3, where all questionnaire items correlated with $\mathrm{r}$ count $\geq \mathrm{r}$ table ( 2 tailed test with a sig. $(\alpha) 0.05$ ) (declared Validity). Researcher used 0.361 from $r$ table as the standard of validity testing.

\begin{tabular}{|c|c|c|}
\hline Variable & Items & R-Compute \\
\hline \multirow{2}{*}{ Performance Expectation } & PE_1 & 0.904 \\
\cline { 2 - 3 } & PE_2 & 0.867 \\
\cline { 2 - 3 } & PE_3 & 0.887 \\
\hline
\end{tabular}




\begin{tabular}{|c|c|c|}
\hline & PE_4 & 0.886 \\
\hline & PE_5 & 0.742 \\
\hline & PE_6 & 0.550 \\
\hline \multirow[t]{4}{*}{ Effort Expectation } & EE 1 & 0.842 \\
\hline & EE 2 & 0.896 \\
\hline & EE 3 & 0.807 \\
\hline & EE 4 & 0.886 \\
\hline \multirow[t]{3}{*}{ Social Influence } & SI 1 & 0.853 \\
\hline & SI 2 & 0.909 \\
\hline & SI 3 & 0.770 \\
\hline \multirow[t]{4}{*}{ Facilitating Condition } & FC 1 & 0.62 \\
\hline & $\mathrm{FC} 2$ & 0.756 \\
\hline & FC 3 & 0.748 \\
\hline & FC 4 & 0.807 \\
\hline \multirow[t]{4}{*}{ Hedonic Motivation } & HM_1 & 0.814 \\
\hline & HM_2 & 0.861 \\
\hline & HM_3 & 0.865 \\
\hline & HM_4 & 0.842 \\
\hline \multirow[t]{3}{*}{ Perceived Technology Security } & PTS 1 & 0.826 \\
\hline & PTS 2 & 0.908 \\
\hline & PTS 3 & 0.915 \\
\hline \multirow[t]{7}{*}{ Trust } & $\mathrm{T} 1$ & 0.856 \\
\hline & $\mathrm{T} 2$ & 0.812 \\
\hline & T3 & 0.824 \\
\hline & $\mathrm{T} 4$ & 0.836 \\
\hline & T5 & 0.866 \\
\hline & T6 & 0.905 \\
\hline & $\mathrm{T} 7$ & 0.868 \\
\hline
\end{tabular}

Table 3. Validity test result

\subsection{Hypothesis Testing}

ANOVA method is to determine whether the means of the various groups are significantly different from one another, as indicated by the F statistic. Such result shown in Table 4 that independent factors (performance expectation, effort expectation, social influence, hedonic motivation, facilitating condition, perceived technology security, and trust) have significant value of 0.000 , lower than 0.05 and $F$ value of 110.188 which is greater than 2.70.The result shows that all independent factors have a significant impact simultaneously on behavioural intention.

\begin{tabular}{|c|c|c|c|c|c|c|}
\hline \multicolumn{7}{|c|}{ ANOVA $^{a}$} \\
\hline \multicolumn{2}{|c|}{ Model } & $\begin{array}{l}\text { Sum of } \\
\text { Squares }\end{array}$ & df & Mean Square & $\mathrm{F}$ & Sig. \\
\hline \multirow[t]{3}{*}{1} & Regression & 2769.253 & 7 & 395.608 & 110.188 & $.000^{\mathrm{b}}$ \\
\hline & Residual & 599.581 & 167 & 3.590 & & \\
\hline & Total & 3368.834 & 174 & & & \\
\hline \multicolumn{7}{|c|}{ a. Dependent Variable: Behaviourallntention } \\
\hline \multicolumn{7}{|c|}{$\begin{array}{l}\text { b. Predictors: (Constant), Trust, Sociallnfluence, EffortExpectancy, TechnologySecurity, } \\
\text { FacilitatingCondition, PerformanceExpectation, HedonicMotivation }\end{array}$} \\
\hline
\end{tabular}

Table 4: F-Test result ANOVA 


\begin{tabular}{|c|c|c|c|c|c|c|}
\hline \multicolumn{7}{|c|}{ Coefficients $^{a}$} \\
\hline \multirow{2}{*}{\multicolumn{2}{|c|}{ Model }} & \multicolumn{2}{|c|}{ Unstandardized Coefficients } & \multirow{2}{*}{$\begin{array}{c}\text { Standardized } \\
\text { Coefficients } \\
\text { Beta }\end{array}$} & \multirow[b]{2}{*}{$t$} & \multirow[b]{2}{*}{ Sig. } \\
\hline & & $\mathrm{B}$ & Std. Error & & & \\
\hline \multirow[t]{8}{*}{1} & (Constant) & -3.103 & .785 & & -3.950 & .000 \\
\hline & PerformanceExpectation & .062 & .058 & .081 & 1.063 & .289 \\
\hline & EffortExpectancy & .186 & .086 & .143 & 2.153 & .033 \\
\hline & Sociallnfluence & .289 & .075 & .212 & 3.876 & .000 \\
\hline & FacilitatingCondition & -.108 & .093 & -.075 & -1.158 & .249 \\
\hline & HedonicMotivation & .552 & .107 & .453 & 5.166 & .000 \\
\hline & TechnologySecurity & .053 & .095 & .033 & .563 & .574 \\
\hline & Trust & .115 & .057 & .154 & 2.026 & .044 \\
\hline
\end{tabular}

Table 5: Multiple Regression Analysis

Table 5 resulted about the multiple regression analysis which found effort expectation, social influence, hedonic motivation, and trust as independent variable, have significant influence towards the dependent variable while performance expectation, facilitating conditions, and perceived technology security have not found to be the significant influence toward the behavioural intention.

\begin{tabular}{|c|c|c|c|c|}
\hline \multicolumn{5}{|c|}{ Model Summary } \\
\hline Model & $\mathrm{R}$ & R Square & $\begin{array}{l}\text { Adjusted R } \\
\text { Square }\end{array}$ & $\begin{array}{l}\text { Std. Error of } \\
\text { the Estimate }\end{array}$ \\
\hline 1 & $.907^{\mathrm{a}}$ & .822 & .815 & 1.895 \\
\hline \multicolumn{5}{|c|}{$\begin{array}{l}\text { a. Predictors: (Constant), Trust, Sociallnfluence, } \\
\text { EffortExpectancy, TechnologySecurity, } \\
\text { FacilitatingCondition, PerformanceExpectation, } \\
\text { HedonicMotivation }\end{array}$} \\
\hline
\end{tabular}

Table 6: Coefficient of determination result

Coefficient of determination, $\mathrm{R}^{2}$, provides information on the excellence of fit of the regression model. Adjusted $\mathrm{R}^{2}$ values $\mathrm{R}^{2}$ that has been adjusted, which is always less than the $\mathrm{R}^{2}$. From the calculation as shown in Table 6 , coefficient determination $\left(\mathrm{R}^{2}\right)$ value is 0.815 which show a correlation of independent variables to dependent variable simultaneously. 


\section{Discussion}

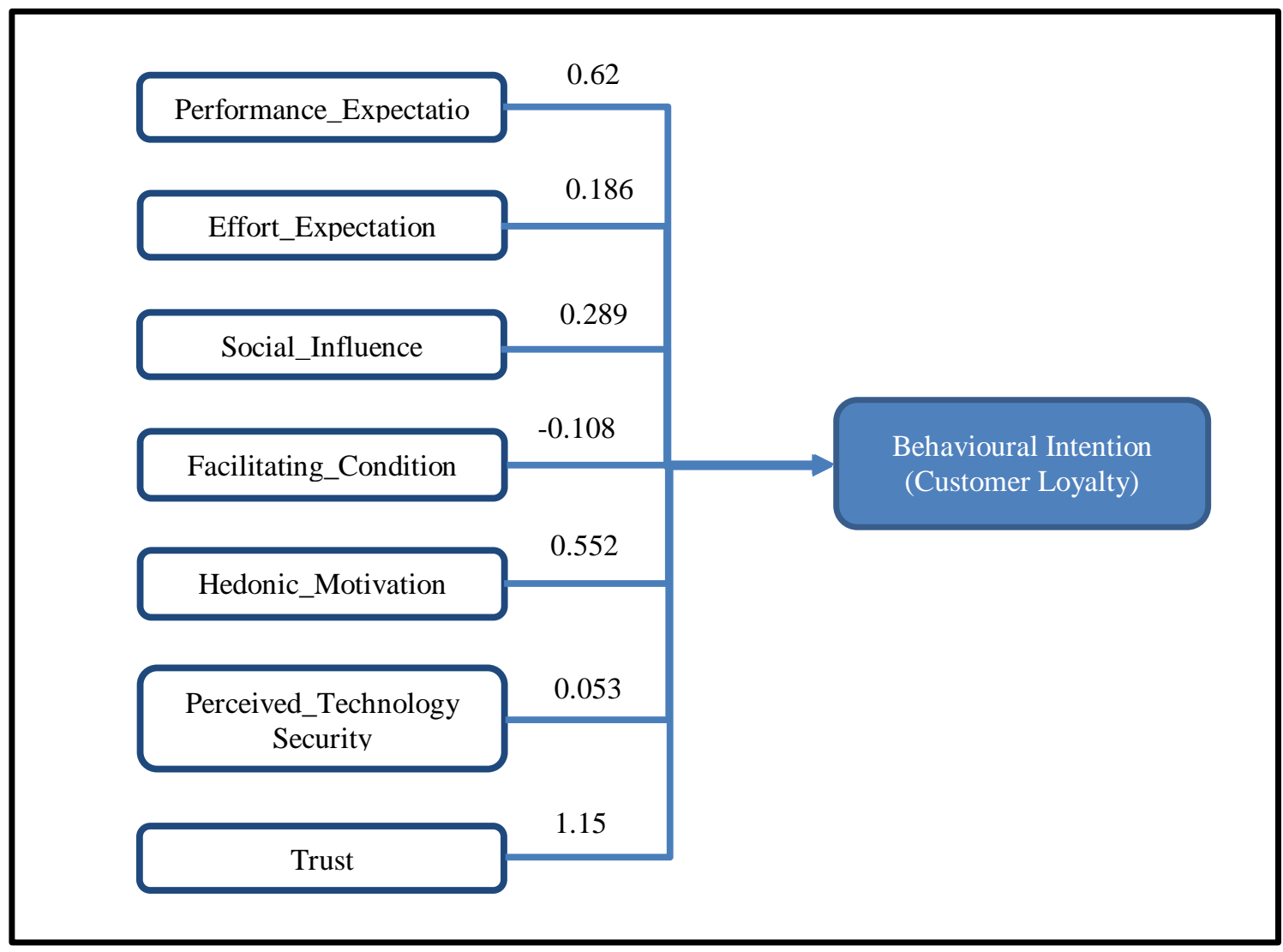

Figure 3: Validated Research Model

Below are the analyses according to the statistical result presented above:

1. The first hypothesis (H1: Does performance expectation has a significant impact on customers loyalty of LinkAja?) was not supported. The hypothesis 1 resulted the performance expectancy variable does not give influence towards the behavioural intention as shown in the significant level of 0.289 which is higher than 0.05 . Thus, we can conclude that performance expectancy has no significant impact on customer loyalty to use LinkAja. However, in Venkatesh et al. (2012) study shows that performance expectancy has impact for interest use of a technology. The difference of the outcome may be due to consumers of LinkAja do not feel that using LinkAja has an impact on saving time for performance improvement.

2. The second hypothesis (H2: Does effort expectation has a significant impact on customer loyalty of LinkAja?) was supported. The result of hypothesis 2 displayed that effort expectancy variable gives significant impact to behavioural intention. As shown in Table 5, the significant test result is 0.033 which is lower than 0.05. Venkatesh et al., (2012) study also shows that there is an impact of effort expectancy on interest use of technology.

3. The third hypothesis (H3: Does social influence has a significant impact on customer loyalty of LinkAja?) was also supported. The result of hypothesis 3 displayed that social influence variable gives significant impact to behavioural intention. Based on the test results, the significant test is 0.000 which is lower than 0.05. It is apparent that the higher the Social Influence, the more likely the consumers use LinkAja. The same variable results shown in Oliveira et al. (2016) study on mobile payment technology.

4. The fourth hypothesis (H4: Does facilitating condition have a significant impact on customer loyalty of LinkAja?) was not supported. The result of hypothesis 4 show that the significant test result is 0.249 which is higher than 0.05 , which implies that facilitating condition variable does not influence the behavioural Intention of LinkAja. Morosan and DeFranco (2016) study showed the same results, that facilitating condition does not influence the Behavioural Intention. However, it is contradict with 
Venkatesh et al., (2012) studies which stated that facilitating conditions can control behaviour individuals in the context of technology.

5. The fifth hypothesis (H5: Does hedonic motivation has a significant impact on loyalty of LinkAja?) was supported. The test result with significant level of 0.000 which is lower than 0.05 . It is apparent that the higher the Hedonic Motivation, the higher the interest of consumers to use LinkAja. Alalwan et al., (2017) study also supports hedonic motivation as a factor that impacts interest the use of technology.

6. The sixth hypothesis (H6: Does perceived technology security has a significant impact on customer loyalty of LinkAja?) was not supported. The result of hypothesis 6 displayed the significant test result is 0.574 which is higher than 0.05 . The results of this research show that Perceived Technology Security does not affect the Behavioural Intention of LinkAja. Morosan \& DeFranco, (2016) study showed that the perceived technology security has no significant influence to the use of mobile payments.

7. The last hypothesis (H7: Does trust have a significant impact on customer oyalty of LinkAja?) was supported. As shown in Table 5, the significant test result is 0.044 which is lower than 0.05 . In this research, the Trust is significantly influence the customer to use LinkAja. Alalwan et al., (2017) study also shows the same result.

\section{Conclusion and Implications}

\subsection{Conclusion}

Effort expectancy, social influences, hedonic motivation, and trust have significant impact on customer loyalty to use LinkAja. The results show that (i) LinkAja is easy to use (user friendly) so that the customer in Jabodetabek wants to continue using the LinkAja as their online payment media, (ii) social influence is a key factor, a positive experience in using LinkAja will increase the customer loyalty, (iii) having fun in using Link Aja is one of the main reason consumer interest in using LinkAja, and (iv) people believe in LinkAja as it is supported by the state owned companies and state-owned banks.

However, the performance expectancy, facilitating condition, and perceived technology security have no significant impact on customer loyalty to use LinkAja. The performance expectancy does not affect the customer loyalty because the Jabodetabek people feel that LinkAja does not help their daily activities. LinkAja provides lack of supporting facilities and features, such as paying at offline merchant. Consumers experience less benefit of using LinkAja compare to other mobile payment application. Consumers' concern about the perceived technology security in the LinkAja application, whether their balance of money deposited on LinkAja is secure enough, which in turn reduce the customer's loyalty to use LinkAja.

\subsection{Implications}

To improve the customer's loyalty to use LinkAja, there are 3 variables to be improved, namely performance expectancy, facilitating condition, and perceived technology security. Following are several suggestions to improve each of the area. For performance expectancy, LinkAja can add more functional features to meet consumer needs by adopting several features from the other mobile payment application. For facilitating condition, researchers recommend LinkAja to add payment tools at each offline merchant, especially with restaurants. In perceived technology security factor, LinkAja should improve the user's personal security, such as protection from fraud. This is important to increase trust in using LinkAja as a mobile payment application.

\section{References \\ Journal and book:}

[1] Alalwan, A. A., Dwivedi, Y. K., \& Rana, N. P. (2017). Factors influencing adoption of mobile banking by Jordanian bank customers: Extending UTAUT2 with trust. International Journal of Information Management, 37(3), 99-110. https://doi.org/10.1016/j.ijinfomgt.2017.01.002

[2] Aydin, G., \& Burnaz, S. (2016). ADOPTION OF MOBILE PAYMENT SYSTEMS: A STUDY ON MOBILE WALLETS. Journal of Business, Economics and Finance-JBEF, 5(1). https://doi.org/10.17261/Pressacademia.2016116555 
[3] Boyd, Kannan, \& Slotegraaf (2019). Branded Apps and Their Impact on Firm Value: A Design Perspective. Journal of Marketing Research. https://doi.org/10.1177/0022243718820588

[4] Carlos Roca, J., José García, J., \& José de la Vega, J. (2009). The importance of perceived trust, security and privacy in online trading systems. Information Management \& Computer Security, 17(2), 96-113. https://doi.org/10.1108/09685220910963983

[5] Fan, J., Shao, M., Li, Y., \& Huang, X. (2018). Understanding users' attitude toward mobile payment use. Industrial Management \& Data Systems, 118(3), 524-540. https://doi.org/10.1108/IMDS-06$\underline{2017-0268}$

[6] Gupta, A., Dogra, N., \& George, B. (2018). What determines tourist adoption of smartphone apps? Journal of Hospitality and Tourism Technology, 9(1), 50-64. https://doi.org/10.1108/JHTT-02$\underline{2017-0013}$

[7] Im, I., Hong, S., \& Kang, M. S. (2011). An International Comparison of 100 Technology Adoption: Testing The UTAUT Model. Information and Management, 48(1), 1-8. https://doi.org/10.1016/j.im.2010.09.001

[8] Kim, C., Tao, W., Shin, N., \& Kim, K.-S. (2010). An empirical study of customers' perceptions of security and trust in e-payment systems. Electronic Commerce Research and Applications, 9(1), 84-95. https://doi.org/10.1016/i.elerap.2009.04.014

[9] Lu, H., \& Yu-Jen Su, P. (2009). Factors affecting purchase intention on mobile shopping web sites. Internet Research, 19(4), 442-458. https://doi.org/10.1108/10662240910981399

[10] Lv, H., Yu, G., and Wu, G. (2018). Relationships among customer loyalty, customer satisfaction, corporate image and behavioural intention on social media for a corporation. International Journal of Information Technology and Management. https://doi.org/10.1504/IJITM.2018.092879

[11] Morosan, C., \& DeFranco, A. (2016). It's about time: Revisiting UTAUT2 to examine consumers' intentions to use NFC mobile payments in hotels. International Journal of Hospitality Management, 53, 17-29. https://doi.org/10.1016/j.ijhm.2015.11.003

[12] Namkung, Y., \& Jang, S. (2007). Does Food Quality Really Matter in Restaurants? Its Impact On Customer Satisfaction and Behavioral Intentions. Journal of Hospitality \& Tourism Research, 31(3), 387-409. https://doi.org/10.1177/1096348007299924

[13] Oliveira, T., Thomas, M., Baptista, G., \& Campos, F. (2016). Mobile payment: Understanding the determinants of customer adoption and intention to recommend the technology. Computers in Human Behavior, 61, 404-414. https://doi.org/10.1016/i.chb.2016.03.030

[14] Phonthanukitithaworn, C., Sellitto, C., \& Fong, M. W. L. (2016). An investigation of mobile payment (m-payment) services in Thailand. Asia-Pacific Journal of Business Administration, 8(1), 37-54. https://doi.org/10.1108/APJBA-10-2014-0119

[15] Popovska-Kamnar, N. (2014). THE USE OF ELECTRONIC MONEY AND ITS IMPACT ON MONETARY POLICY. In JCEBI (Vol. 1 ). https://www.econstor.eu/bitstream/10419/147460/1/86795244X.pdf

[16] Saha, G. C., \& Theingi. (2009). Service quality, satisfaction, and behavioural intentions. Managing Service Quality: An International Journal, 19(3), 350-372. https://doi.org/10.1108/09604520910955348

[17] Schierz, P. G., Schilke, O., \& Wirtz, B. W. (2010). Understanding consumer acceptance of mobile payment services: An empirical analysis. Electronic Commerce Research and Applications, 9(3), 209-216. https://doi.org/10.1016/i.elerap.2009.07.005

[18] Sugiyono (2010) MetodePenelitian Kuantitatif Kualitatif \& RND. Bandung : Alfabeta

[19] Venkatesh, V., Smith, R. H., Morris, M. G., Davis, G. B., Davis, F. D., \& Walton, S. M. (2003). USER ACCEPTANCE OF INFORMATION TECHNOLOGY: TOWARD A UNIFIED VIEW 1. In User Acceptance of IT MIS Quarterly (Vol. 27). Retrieved from http://www.vvenkatesh.com/wpcontent/uploads/2015/11/2003(3) MISQ Venkatesh etal.pdf

[20] Venkatesh, V., Thong, J. Y., \& Xu, X. (2012). Consumer acceptance and use of information technology: extending the unified theory of acceptance and use of technology. MIS quarterly, 36(1), 157-178. Retrieved from 
https://pdfs.semanticscholar.org/6256/0e2001480fd1f22558ce4d34ac93776af3e6.pdf

[21] Zhou, T. (2013). An empirical examination of continuance intention of mobile payment services. Decision Support Systems, 54(2), 1085-1091. https://doi.org/10.1016/j.dss.2012.10.034

\section{Website:}

[1] Iprice (2019), Siapa Aplikasi E-wallet dengan Pengguna Terbanyak di Indonesia?. Retrieved Aug 2019, from https://iprice.co.id/trend/insights/e-wallet-terbaik-di-indonesia/

[2] Katadata.co.id. (2019). LinkAja, Koalisi 7 BUMN Saingi Go-Pay dan OVO | Katadata News. Retrieved April 23, 2019, from https://katadata.co.id/infografik/2019/03/11/linkaja-koalisi-7-bumn-saingigo-pay-dan-ovo

[3] Basari, M. (2019). Setahun, Jumlah Pengguna Internet Indonesia Bertambah 17 Juta. Retrieved April 20, 2019, from https://teknologi.bisnis.com/read/20190228/101/894799/setahun-jumlahpengguna-internet-indonesia-bertambah-17-juta

[4] Multazam, Muhammad. (2019). Terlena Dompet Digital. Retrieved April 20, 2019, from https://news.detik.com/kolom/d-4463578/terlena-dompet-digital

[5] The Jakarta Post (2019), The top five e-wallet apps in Indonesia. Retrieved Aug, 2019, from https://www.thejakartapost.com/life/2019/08/14/the-top-five-e-wallet-apps-in-indonesia.html 